\title{
ДИВЕРСИФІКАЦІЯ ПІДХОДІВ ДО ВИВЧЕННЯ ЕЛЕКТРОТЕХНІКИ ТА ЕЛЕКТРОНІКИ ПЕДАГОГАМИ ПРОФЕСІЙНОГО НАВЧАННЯ
}

\begin{abstract}
У статті розглянуто мету і впровадження диверсифікаиіі у прочесі вивчення електротехніки та електроніки майбутніми педагогами професійної освіти. Обгрунтовано, що диверсифікаиія змісту сприяє трунтовному засвоєнню теоретичного матеріалу, який органічно пов'язаний з практикою. Розкрито диверсифікачію підходів у формуванні нестандартного творчого мислення студентів. Запропоновано системний інновачійний підхід, який дає можливість впровадження диверсифікаиійних методів при викладанні матеріалу з електротехніки та електроніки для майбутніх педагогів професійної освіти. $B$ основу покладено застосування диверсифікащиї на різних етапах занять, що дозволяє раціональніше розподілити час, сприяє покращченню емоиійного сприйняття матеріалу, підвищенню його інформативності, доступності та наочності.
\end{abstract}

Ключові слова: диверсифікачія, електротехніка, електроніка, педагог професійного навчання.

Застосування диверсифікаційних прийомів у навчанні заохочує молодь до самостійної творчої і пошукової праці, метою якої є здобуття знань та успішне їх застосування у профресійній діяльності. Диверсифрікація сприяє проникненню і злиттю тих ефективних методів і прийомів, які використовуються у викладанні суміжних дисциплін. Це створює сприятливі умови для розширення знань на снові їхньої варіативності. Пошук нових можливостей завжди дає позитивний результат.

В освітній системі сучасного українського суспільства, як і в більшості соціальних інститутів загалом, впроваджується низка нововведень. Диверсифрікація - одна із них. Варто зауважити, що процеси, котрі мають місце в суспільстві, відображаються на освітній системі, не звертаючи увагу на її консервативність. Адже криза системи освіти торкається всіх ії прошарків, а найбільше - вищої професійної освіти. Аналіз джерел із проблеми модернізації вищої освіти як закономірного соціокультурного процесу (Р. Абдєєв, В. Автономов, Р. Акофф, С. Алексєєва, В. Андрущенко, Ю. Бондарчук, Д. Гелбрейт, М. Євтух, І. Зязюн, М. Каган, В. Кремень, М. Лапін, В. Мєдвєдєв, М. Моісєєв, В. Онушкін, В. Пожуєв, І. Пригожин, М. Рижаков, О. Ходаковський, В. Цаплін, В. Ядов, Ф. Янсен та ін.), наукових узагальнень із питань реформування та модернізації вищої і професійної освітив Україні (В. Андрущенко, А. Алексюк, В. Бондар, О. Ляшенко, О. Мороз, М. Ярмаченко та ін.) дає можливість зробити висновок, що дієвим творчим чинником професійної освіти має стати її різноманітність, різнобічний розвиток і глибока інтеграція всіх освітніх підсистем i процесів. Питанням дослідження диверсифікаційних процесів присвятили свої праці М. Багорка, І. Білоткач, О. Ковтун, М. Корінько, Г. Пересадько, В. Цимбалта ін. Оновлення системи професійної освіти обумовлено необхідністю вирішення існуючого сьогодні 
протиріччя між потребою будь-якого фрахівця в розмаїтті освітніх послуг і корпоративністю, відомчою роз'єднаністю освітніх структур, замкнутістю й самоізоляцією в багатьох аспектах їх діяльності: змістовному, організаційному, кадровому. Тому модернізація системи вищої професійної освіти сьогодні неможлива без їі диверсифрікації.

Метою статті є: уточнення змісту поняття "диверсифікація професійної освіти", визначення суті поняття "диверсифрікація управління професійною освітою", їх істотних ознак, що дають системне представлення даного явища, розкриє механізм його існування і розвитку.

По суті, саме поняття диверсифікація (від лат. diversicatio) - означає зміну та різноманіття, тобто різноманіття рівнів та форм отримання освіти (поява ступенів "бакалавр", “спеціаліст”, “магістр”, полі- та монопрофресійної освіти і т.д.).

Уперше про диверсифрікацію як про модерне явище в економіці заговорили наприкінці 50-х років XX ст. Воно було пов'язане з концентрацією капіталу в умовах науково-технічної революції. Фірми розвинутих країн, прагнучи вижити при шаленій конкуренції, почали проникати у нові для себе галузі і сорери.

Диверсифрікаційні нововведення не залишили поза увагою і освітню галузь. Початок 70-х років ознаменувався урізноманітненням структури освітніх систем у Західній Европі. Так почався процес розповсюдження вибору освітніх послуг через широке впровадження варіативних освітніх програм у навчальних закладах, що невпинно зростали й розвивалися.

Це стало твердою підставою для отримання якісної освіти, яка повинна задовольняти попит на висококваліфікованого, конкурентноздатного педагога залежно від ринкової кон'юнктури.

Отже, диверсифікація економіки безпосередньо вплинула на зміну структури в освітній галузі, що забезпечує варіативність освітніх послуг,освітніх програм, типів і видів освітніх установ. Потужний інноваційний потенціал підняв педагога як цілісну творчу особистість, здатну орієнтуватися у світі, сповненому новацій і викликів, та приймати відповідальні рішення на духовні запити суспільства. Саме на сучасному етапі входження України до єдиного європейського та світового освітнього простору зростає значимість диверсифікації підходів навчання електротехніки і електроніки для майбутніх педагогів професійної освіти.

Наразі існує сукупність принципів диверсифікації:

1) принцип відповідності - задоволення потреби у випускниках, здатних вирішувати комплексні завдання сучасного виробництва;

2) принцип якісної освіти - необхідність підвищення якості загальноосвітньої і професійної підготовки в освітніх установах та рівня вимог до кваліфрікації професійних кадрів;

3) принцип особистісної спрямованості - задоволення потреб особистості в різноманітті освітніх послуг;

4) принцип свободи вибору - розширення свобод освітніх установ у наданні освітніх послуг. 
Реалізація принципів диверсифікації забезпечує розвиток педагогічної системи базової загальної освіти та освітніх установ, що сприяє входженню України в світовий простір, за умови інтеграції з іншими принципами розвитку сучасної системи.

Диверсифрікацію професійної освіти розглядають як “процес розширення асортименту освітніх послуг" [1, с. 383]. Широке розмаїття навчальних закладів, освітніх програм і органів управління, впровадження різноманітних освітніх послуг, реалізація принципів альтернативності й варіативності, забезпечення якості освіти - усе це має задовольняти зростаючий попит споживачів залежно від кон'юнктури ринку.

У філософрсько-педагогічному аспекті вектор процесу диверсифікації освіти спрямований на гуманізацію і демократизацію освітніх систем, фрормування нових життєвих установок особистості, гуманізацію суспільно-економічних відносин, що вимагає переходу від технократичного підходу (знаннєвого) до ідеології орієнтації на розвиток особистості фрахівця, формування в нього таких якостей як самостійність, творча активність, уміння орієнтуватися в мінливому світі, приймати відповідальні рішення в нестандартних ситуаціях, досягати максимально можливих результатів (особистісний підхід). Отже, освіта в умовах диверсифікації стає могутньою рушійною, ініціативною силою економічного зростання держави, підвищенням ефективності й конкурентоспроможності народного господарства, одним із фракторів національної безпеки і заможності країни; основою перетворення суспільства на відкриту, варіативну, діалогічну, толерантну систему, що забезпечує становлення конкурентоздатних фрахівців [2, с. 26]. Учені досліджують різні види диверсифрікації, виділяючи диверсифікацію освітніх установ (різноманітність освітніх установ), програмнопрофрільну (надання послуг з різних напрямів і програм), технологічну (інформаційні, інтерактивні та інші технології, перехід від демонстраційних засобів до навчальних), структурну (зв'язок з адміністративно-територіальними умовами діяльності навчальних закладів тощо) [3, с. 123]; диверсифікацію системи професійної освіти на основі використання дуальних програм, що дають змогу збільшити різноманітність пропонованих професійних програм, сприяють більш різнобічному професійному розвитку учнів, забезпечують взаємозв'язок, взаємопроникнення і взаємовплив різних систем (наука і освіта, наука і виробництво); суспільну диверсифрікацію (кожна людина має право на різні національно-етичні, мовні, фрізичні, статеві, поведінкові відмінності, які роблять особистість унікальною і які необхідно визнавати, поважати, цінувати) тощо [4, с. 127].

Запровадження диверсифікації в освітню галузь свідчить про її широке застосування в поліпшені підготовки кадрового потенціалу, підвищенні кваліфікації, різносторонньому професійному розвитку майбутніх педагогів зі спеціальності “Профресійна освіта" у процесі вивчення електротехніки та електроніки.

Зараз неймовірно швидкісними темпами розвивається електротехніка та електроніка. Щоб встигнути розібратися в цих приголомшливих новинках, 
майбутнім педагогам необхідно йти в ногу з часом, адже доведеться навчати учнів системи профтехосвіти усьому новому. Тут потрібно не просто ознайомити з матеріалом, а викликати інтерес до здобутт знань. Диверсифікація підходів до навчання студентів у ВЗО пробуджує самостійне мислення, творчу діяльність. Комп'ютерні технології в руках викладача ефективний засіб навчання, що дозволяє впроваджувати в лекційний матеріал різні форми та прийоми навчання, полегшувати та вдосконалювати виконання творчих робіт, проектів, рефератів, презентацій [5, с. 132]. Використання інноваційних технологій поряд із традиційними урізноманітнює навчальний процес. Сьогодні $є$ великий вибір програмного забезпечення для створення віртуальних моделей для лабораторного експерименту, готових моделей окремих лабораторних робіт або цілих віртуальних лабораторій 3 електротехніки та електроніки. Використання віртуальних лабораторних практикумів у певній методичній системі буде ґрунтуватися на оптимальному поєднанні реального і віртуального експерименту, що дозволить студентам засвоїти необхідні компетенції щодо дослідження динаміки процесів у електричних колах за умови зміни певних параметрів або порушень режимів роботи. Віртуальний лабораторний практикум дозволяє продемонструвати сутність складних внутрішніх фрізичних процесів, що мають місце в електричних машинах, приладах, пристроях, причому в динаміці. Наприклад, наочно показати принцип дії електричних машин, рух основних і неосновних носіїв заряду в напівпровідниках, зміни ширини забороненої зони в залежності від характеру внесеної у напівпровідник домішки, зменшення чи збільшення потенціального бар'єру при проходженні прямого чи зворотного струму крізь p$\mathrm{n}$ перехід тощо. При наявності обох практикумів студенти мають можливість паралельно та практично одночасно виконати роботи на "віртуальному" й фрізичному стендах частковий (за навчальною програмою) чи повний об'єм лабораторних робот з навчальної дисципліни, що приведе до більш міцній виробці необхідних навичок та вмінь.

Диверсифікація підходів у викладанні електроніки та електротехніки дає студентові можливість навчитися творчості, оригінальності, гнучкості, узагальненню, абстрагуванню, виділенню істотних ознак, аналізу,синтезу, повноцінного розуміння і засвоєння матеріалу. У сучасній методиці відбувається руйнування усталеного досвіду, подолання і переосмислення догматичних стереотипів за рахунок пошуку нових, незвичайних і ніби прихованих прийомів.

Диверсифікувати, тобто урізноманітнити традиційний підхід до викладу матеріалу можна на будь-якому етапі лекції. Для активізації пізнавальної діяльності студентів чинне місце займає метод проблемного викладу.

На лекціях з електротехніки та електроніки можна використати проблемний підхід під час вивчення окремих тем. Основою цього методу $є$ створення на лекції проблемної ситуації. Студенти не володіють знаннями або способами діяльності для пояснення фрактів і явищ, висувають свої гіпотези, рішення даної проблемної ситуації. Даний метод сприяє фрормуванню в 
студентів прийомів розумової діяльності, аналізу, синтезу, порівняння, узагальнення, та встановлення причинно-наслідкових зв'язків [6, с. 85].

Проблемний підхід включає логічні операції, необхідні для вибору доцільного рішення. Ефективність навчального процесу несумісна 3 перевантаженням психічної діяльності його учасників. Застосування комп'ютерної техніки з дотриманням зазначених вимог здатне значно підвищити продуктивність праці учасників педагогічної діяльності за рахунок високоякісної передачі навчального матеріалу, концентрації уваги на вузлових моментах навчального матеріалу, і водночас зменшити непродуктивні втрати сил та часу на пошук, обробку, сприймання і засвоєння інформації [7, с. 23].

Специфікою лекцій з електротехніки та електроніки $є$ необхідність досить часто використовувати наочність як у вигляді стаціонарних її фрорм (графіків, рисунків, схем тощо). За допомогою комп'ютера із спеціальним проектором легко можна показувати досліди, проведення яких ускладнено чи то громіздкістю необхідної апаратури чи то іншими причинами. Викладач не тільки пояснює навчальний матеріал, а й організовує пізнавальну діяльність студентів. Починається виклад матеріалу з повідомлення теми. Перш за все треба показати необхідність вивчення теми і логіку вивчення кожного її питання. Важливо викликати інтерес до теми. Для цього можна навести цікаві факти встановлення закону, показати досліди, які учні зможуть пояснити в ході розгляду теми, вказати пізнавальні задачі. Адже усвідомлення мети діяльності $\epsilon$ необхідною умовою будь-якої вольової дії [8, с. 34].

Це повністю залежить від викладача, який спрямовує розумову діяльність студентів у визначеному ним напрямку, використовуючи міжпредметні зв'язки.

Висновки. Диверсифікація підходів до вивчення електротехніки та електроніки педагогами професійного навчання особливо актуальна на сьогоднішній день, коли освіта в Україні впевнено вибрала кардинально новий шлях розвитку. Тому перед педагогом стоїть важливе завдання - на основі диверсифікації впровадити нові форми і прийоми у викладанні програмного матеріалу. Це дозволяє поєднати активну творчість викладача і студента, щоб покращити якість засвоєння знань.

\section{Використана література:}

1. Вітковський О. Застосування портфельних теорій для оцінки ефективності диверсифікації діяльності підприємства. Підприємство, господарство і право. 2006. № 9. С. 166-168.

2. Нова школа. Простір освітніх можливостей / М-во освіти і науки України ; упоряд. : Л. Гриневич, О. Елькін, С. Калашнікова [та ін.] ; за заг. ред. М. Грищенко. Київ, 2016. 40 с.

3. Олійник В. В. Сьогодення та перспективи розвитку післядипломної педагогічної освіти. Пост Методика. 2012. № 4 (107). С. 2-6.

4. Михайлева Е. Диверсифікація університетів: світова практика та вітчизняний досвіт /Е. Михайлева [Електроний ресурс]. Режим доступу: http://irbisnbuv.gov.ua/cgibin/irbis_nbuv/ cgiirbis_64.exe?C21COM=2\&I21DBN=UJRN\&

P21DBN=UJRN\&IMAGE_FILE_DOWNLOAD=1\&Image_file_name=PDF/Mtpsa_2014_20_53.pdf.

5. Ковальчук В. Ю. Модернізація професійної та світоглядно-методологічної підготовки сучасного вчителя : дис. .... д-ра пед. наук : 13.00.04. Київ, 2005. 402.

6. Енциклопедія освіти / Акад. пед. наук України ; [гол. ред. В. Г. Кремень]. Київ : ЮрінкомІнтер, 2008. $1040 \mathrm{c}$. 
7. Івашковський В. Створення належних педагогічних умов - визнана складова процесу виховання громадянина. Рid. шк. 2008. № 9. С. 36-39.

\section{References:}

[1] Vitkovskyi O. Zastosuvannia portfelnykh teorii dlia otsinky efektyvnosti dyversyfikatsii diialnosti pidpryiemstva. Pidpryiemstvo, hospodarstvo i pravo. 2006. № 9. S. 166-168.

[2] Nova shkola. Prostir osvitnikh mozhlyvostei / M-vo osvity i nauky Ukrainy ; uporiad. : L. Hrynevych, O. Elkin, S. Kalashnikova [ta in.] ; za zah. red. M. Hryshchenko. Kyiv, 2016. 40 s.

[3] Oliinyk V. V. Sohodennia ta perspektyvy rozvytku pisliadyplomnoi pedahohichnoi osvity. Post Metodyka. 2012. № 4 (107). S. 2-6.

[4]. Mykhaileva E. Dyversyfikatsiia universytetiv: svitova praktyka ta vitchyznianyi dosvit / E. Mykhaileva [Elektronyi resurs]. Rezhym dostupu: http://irbisnbuv.gov.ua/cgibin/irbis_nbuv/cgiirbis_64.exe? $\mathrm{C} 21 \mathrm{COM}=2 \& \mathrm{I} 21 \mathrm{DBN}=\mathrm{UJRN} \& \quad$ P21DBN=UJRN\&IMAGE_FILE_DOWNLOAD=1\&Image_file_ name=PDF/Mtpsa_2014_20_53.pdf.

[5]. Kovalchuk V. Yu. Modernizatsiia profesiinoi ta svitohliadno-metodolohichnoi pidhotovky suchasnoho vchytelia : dys. ... d-ra ped. nauk : 13.00.04. Kyiv, 2005. 402.

[6] Entsyklopediia osvity / Akad. ped. nauk Ukrainy ; [hol. red. V. H. Kremen]. Kyiv : YurinkomInter, 2008. $1040 \mathrm{~s}$.

[7] Ivashkovskyi V. Stvorennia nalezhnykh pedahohichnykh umov - vyznana skladova protsesu vykhovannia hromadianyna. Rid. shk. 2008. № 9. S. 36-39.

\section{Дидык А. О. Диверсификация подходов к изучению электротехники и электроники педагогами профессионального обучения.}

В статье рассмотрено иель и внедрение диверсификаиии в преподавании электротехники и электроники для будущих педагогов профессионального образования. Акиентировано внимание на то, что диверсификация способствует глубокому усвоению теоретического материала, который органично связанный с практикой. Раскрыто диверсификацию подходов в формировании нестандартного творческого мышиления студентов. Предложен системньй инновачионный подход, который дает возможность внедрения диверсификационных методов при преподавании материала по электротехнике и электронике для будущих педагогов профессионального образования. В основу положено применения диверсификачии на разныл этапах занятий, что позволяет более ращионально распределить время, способствует улучшению эмочионального восприятия материала, повыпению его информативности, доступности и наглядности.

Ключевые слова: диверсификация, электротехника, электроника, педагог профессионального обучения.

\section{DIDYK A. O. The diversification of approaches to learning of electrical engineering by teachers of professional training. \\ The purpose and introduction of diversification in the process of studying electrical engineering and} electronics by future teachers of vocational education are considered in the article. It is substantiated that content diversification contributes to a thorough assimilation of theoretical material that is organically linked to practice. The diversification of approaches in forming of non-standard creative thinking of students is revealed. A systematic innovative approach is proposed that enables the introduction of diversification methods in teaching material in electrical engineering and electronics to future professional education teachers. The basis is the use of diversification at different stages of employment, which allows a more rational allocation of time, helps to improve the emotional perception of the material, increase its informativeness, accessibility and clarity.

Keywords: diversification, electrical engineering, electronics, professional training teacher. 